\title{
Who is a convert? \\ New members of the Orthodox Church in Norway
}

\author{
BERIT SYNØVE THORBJØRNSRUD \\ University of Oslo
}

\begin{abstract}
Due to its recent major revival in the post-Soviet period, the Orthodox Church can today be described as a church of new believers. While this seems to be acknowledged at a general level, there is a strong tendency to avoid speaking of new members with an Eastern European background as 'converts'. Although they have often gone through much greater transformations - from atheism to Orthodoxy - than those with a Western background, who generally seem to have a Christian past, the term convert is generally reserved for the Westerners. 'It is not our custom to call them converts', one of the priests in Norway commented. Conversion stories which gain international publicity are generally about Westerners, and even the few academic studies on converts to Orthodoxy have focused solely on those with a Western background. Based on fieldwork among the Orthodox in Norway, I will compare newcomers with a Western background with those with an Eastern European background, and I will argue that convert as an analytical concept may be equally useful in relation to members of both groups. This concept covers, however, a wide range of transformations, and it is thus important to identify precisely what kinds of converts there are among the many new Orthodox believers.
\end{abstract}

Keywords: Converts, The Orthodox Church, Norway, independence

'I am so grateful for the chance to atone,' says Tatiana, who once excelled in refuting God's existence scientifically. 'I used to speak against God, but now I speak up for God!' Like millions of Eastern Europeans who were socialized into the atheist worldview of the former communist regimes, Tatiana discovered religion in the 1990s, and joined the Orthodox Church. The transformation from atheist to devout Orthodox involved, she says, having 'to learn everything anew,' a task which Tatiana enthusiastically embraced.

In the diaspora, Eastern European new believers like Tatiana are continuously being joined by a steady trickle of Western newcomers. In fact, due to a recent major revival in the post-Soviet period, the Orthodox Church can today, to some extent, be described as a church of new believers. While this 
seems to be acknowledged at a general level, there is a strong tendency to avoid speaking of people with an Eastern European background as 'converts'. The term convert, commonly used about newcomers with a Western background, is in fact rarely used about Eastern Europeans. Conversion stories which gain international publicity are generally about Westerners (for example Mathewes-Green 2006), and even the few academic studies on converts to Orthodoxy in the West have focused solely on those with a Western background (Hvithamar 2006, Denmark; Slagle 2011, USA; Kapalò 2014, Ireland).

'It is not our custom to call them [Eastern Europeans] converts', one of the priests in Norway commented, when asked about this tendency to distinguish between new believers according to their geographical background. He would, in other words, not categorize Tatiana as a convert. But why isn't Tatiana, who changed her worldview quite drastically, perceived as a convert? Why is her transformation perceived as different from the transformation of those with a Western background?

Based on fieldwork among the Orthodox in Norway, I will compare newcomers with a Western background with those with an Eastern European background. ${ }^{1}$

Although the Orthodox themselves tend to reserve the term convert for Westerners only, I will argue that convert as an analytical concept may be equally useful with reference to both groups. This concept covers, however, a wide range of transformations, and it is thus important to identify precisely what kinds of converts there are among the new Orthodox. Why have they decided to join the Orthodox Church? To what extent has their choice affected their everyday lives? Do they remain Orthodox over time, or do they, as many contemporary converts do, after a while move on to another faith?

1 During 2006 and 2007 I visited various congregations extensively, particularly in Oslo, where the majority of the Orthodox live. I participated in various activities, engaging in informal conversations, and carried out semi-structured interviews with approximately 80 people (clergy, laity, and high level church leaders). My initial focus was on the jurisdictional pluralism in the diaspora, but as many of the interviewees turned out to be newcomers to the Church (38), I included questions on when, how and why they had become Orthodox. Generally such initial questions were sufficient to make them recount the stories of their conversions. Then I followed up with questions about the reactions of their families and friends; to what extent they were practicing Orthodoxy (praying, fasting, attending liturgy, etc.); and whether they had ever regretted their decision and considered 'moving on'. Generally people responded positively to such questions. Belonging to a small 'invisible' minority, many embraced the opportunity to talk about what they considered an important aspect of their identity. All names are however pseudonyms. Since 2007 I have kept in touch with some of the congregations and I have met with several of the converts interviewed. 
In contemporary society a great number of people seem to be on the move religiously/spiritually. Danièle Hervieu-Léger notes that there is a sharp increase in conversions in Western societies (2008). Globally, millions of people convert (Roy 2013, 177). The fact that so many people convert has, in turn, had an impact on what conversion nowadays involves. As Marzouki points out, there is often a significant difference between past and present conversions $(2013,2)$.

\section{What is a convert?}

Traditionally conversion was understood in terms of St. Paul's sudden and dramatic transformation on the road to Damascus. Although this model of an extreme, externally initiated transformation of an unprepared, passive individual may always have had only an approximate relationship to the experience of actual people embracing a new faith, today, at least, such a perception of conversion is widely contested. Contemporary scholars agree that the term conversion includes a wide range of kinds or degrees of transformation (McGuire 1997, Hervieu-Léger 1999, Ahlin 2005, Marzouki \& Roy 2013). They speak of conversion more in terms of a process than in terms of a single dramatic event, and they describe converts more as active seekers making individual choices, than as passive objects played upon by external forces. They also emphasize contemporary converts' tendency to convert several times, developing what may be described as conversion careers, and they argue that the once-and-for-all aspect of St. Paul's conversion has become rare.

Scholars like Thomas Luckmann, Peter Berger, Paul Heelas and Lars Ahlin even question whether it is meaningful to apply the concepts conversion/convert to people who may move between faiths as they wish, and who may establish private belief systems based on independently selected components from available faiths (in Ahlin 2005). Inspired by Zygmunt Bauman, Lars Ahlin claims that the typical pattern today among those recruiting into religious movements are 'religious tourists', in constant movement towards greater fulfillment, while 'religious pilgrims', choosing to adopt and adhere wholeheartedly and permanently to a new coherent belief system, have become a minority (ibid,17). Additionally, Ahlin distinguishes a third category, of 'refugees', i.e. people ashamed of being relegated to the periphery of their societies, who seek refuge in fundamentalist kinds of religion (ibid). In order to avoid diluting the concept of conversion too much, Ahlin, Luckmann and Helaas are in favor of reserving the term conversion 
for distinct changes which involve people committing to an exclusive canon establishing the truth about this world and the next (in Ahlin 2005,36).

Scholars like McGuire (1997), Hervieu-Léger (1999), Marzouki (2013), and Roy (2013) also distinguish between various kinds and/or degrees of transformation which contemporary conversions involve, but this does not discourage them from retaining the concepts. McGuire distinguishes, however, between conversion which involves 'a transformation of one's self concurrent with a transformation of one's basic meaning system', and 'denomination switching', which involves 'a change of affiliation from one organization to another' mainly for pragmatic reasons without any evident changes in worldview $(1997,71)$.

The concept of 'religious pilgrim' fits well with the Orthodox Church's understanding of conversion; what it wants are committed new believers who will remain Orthodox. Whether such religious pilgrims are what they actually get is however another question. In the case of Norway, are the converts truly 'pilgrims', or possibly 'tourists' passing by?

As noted, Ahlin claims that religious pilgrims only represent a minority of those adopting a new religious allegiance in contemporary society. In a global perspective, his claim may seems questionable, but in relation to Western Europe it seems valid. Grace Davie argues that Western Europe represents an exceptional case; it is far more secularized than the rest of the world, and the prevailing religiosity is characterized by people 'believing without belonging' or 'belonging without believing' (2002). In other words, some people may believe without committing to one belief system and one community, while others may remain members of their traditional religious communities without sharing their beliefs.

Orthodox converts, however, are expected to be religious pilgrims, believing and belonging. As such, then, in Western Europe they will belong to a minority among religious recruits. But who are these converts who supposedly constitute an exception within the exceptional case? How do they explain their decision to become Orthodox? And are there any fundamental differences between the narratives of Eastern European and Western newcomers?

\section{How does one become Orthodox?}

Access to Orthodoxy is protected by clergy, who serve as gatekeepers protecting the theological and social boundaries of Orthodox Christianity (Slagle 2011, 63). In order to be allowed to pass across the ecclesial border, potential 
converts must, in principle, prove themselves worthy. Initially one must be formally accepted as a catechumen, i.e. 'one receiving instruction in the basic doctrines of Christianity before admission to communicant membership in the Church' (Andrews n.d.). Catechumens are required to attend services regularly, socialize with other Orthodox, study, and gradually integrate Orthodox praxis into their everyday life. When they feel ready and the priests in charge agree, they may proceed to admission into the Church.

First, the converts make a full confession. Afterwards they are ritually led from the church entrance towards the sanctuary while they make specific promises and perform specific prayers. Then they are baptized and anointed with the oil of chrism, and finally they are allowed to receive Holy Communion. Generally the converts are given an additional Christian or Saint's name, but they don't change their names legally.

Most Orthodox Churches don't re-baptize those who have already received a Trinitarian baptism. Roman Catholics who have already received the chrism in the sacrament of confirmation are not re-anointed. What the conversion ritual involves depends, in other words, on the converts' religious past.

The cathecumenate is however not always practiced in the prescribed way. While priests in Greece and in Eastern Europe apparently often receive new believers without demanding any such instruction period, in Western countries it seems to be obligatory for converts with a Western background. New believers with an Eastern European background appear however to be accepted without.

In Norway the priests tend to postpone accepting anyone as a catechumen until they are certain of their seriousness. Then they expect Westerners to spend at least a few months, sometimes as much as a full year, as catechumens, since they want to ascertain that the converts understand what being Orthodox involves. None of the priests demand in-depth theological studies, but they do want to ensure that the desire to convert is not merely a result of a holiday infatuation with Greece or Russia. 'There are too many who want a quick fix,' according to one of the priests. Some come with 'fancy demands for when and where their conversion is to take place', demonstrating what he considers a 'know-it-all-attitude'.

'Be aware of those running away,' Father John Garvey, in the USA, advises his colleagues, i.e. Christians fleeing from, for example, the introduction of female priests (1996). To Fr. Garvey it is clearly important to distinguish between conversion from something and conversion to Orthodoxy, and it is of course the latter that the Orthodox Church favors. In principle, the only 
acceptable reason for converting to the Orthodox Church is that 'you are convinced that it is for your personal salvation.'(Anon. 2001.)

The role of the clergy in protecting ecclesial borders, and enforcing demands on potential converts, emphasizes that Orthodoxy is only for those 'certified' as worthy. This adds, of course, to Orthodoxy's spiritual capital (Slagle 2011, 63). However, as noted, newcomers with an Eastern European background are regularly allowed to pass across the border without this 'certification'. They seem to be considered as already inside, as if they are intrinsically Orthodox.

\section{The Orthodox Church in Norway}

The Orthodox Church was established in Norway by refugees from the Russian revolution in the 1920s. From the 1960s onwards, Orthodox from Greece and Yugoslavia arrived in search of work, and the Greeks quickly established an independent congregation. After the fall of communism, an increasing number of Eastern Europeans began immigrating, and during the civil war in former Yugoslavia many Serbs arrived as refugees. Gradually the Serbs, the Bulgarians and the Rumanians established separate congregations, and finally a group mainly of Russians established a second, distinct 'Russian' congregation. While the number of Orthodox have increased from approximately 1000 (in 1990) to 12-13 000 (2014), the number is still small.

In Norway more than 80 per cent of the population belongs to a religious group (2013). The majority, 75.2 per cent, belong to the Norwegian (Lutheran) Church, which until 2012 was a state church. Among the other Christian denominations too, the Catholic and the Pentecostal are the most numerous. There are also Muslim, Buddhist, Hindu, Sikh, Jewish and New Age inspired denominations. In spite of such religious pluralism, Norway may be described as predominantly secular/Lutheran.

Converts to Catholicism and to Islam are relatively often portrayed in mainstream media, but converts to Orthodoxy are rarely mentioned outside the media catering to Christian audiences. Few Norwegians seem to be aware of the Orthodox Church's existence in Norway, and the term Orthodox is often confused with other terms like fundamentalist/fanatic. Consequently, when someone decides to become Orthodox, they join a marginal church, which suffers from the 'usual' problems of the Orthodox diaspora: divisions, lack of cooperation, etc. (Chaillot 2006, Thorbjørnsrud 2015). Still, there is a continuous stream of new converts finding their spiritual home in the Orthodox Church. 
When I raised the topic of converts, both laity and clergy seemed to take it for granted that I wanted to know about newcomers with a Western background. When I asked some of the priests why, they explained that it was their custom to do so, or rather it was not their custom to describe new members with an Eastern European background as converts. When I kept asking why not, and why they didn't test Eastern Europeans the way they do with the Westerners, they argued that this was because 'it is easier for Eastern Europeans originating from Orthodox countries to understand and integrate Orthodoxy in their lives.' While the Westerners were described as having 'no previous experience with Orthodox culture, and no Orthodox support system in their social environment,' the priests seemed to take it for granted that those from Eastern Europe, i.e. from 'Orthodox countries', all have such support systems. They explained that those from the West 'will have to look everything up in books; they will have to study, to reflect and make choices all the time,' while the others apparently 'will know much more intuitively what to do.' They have 'another starting point belonging to an Orthodox culture', and thus, it will be 'easier for them to adapt to Orthodox requirements.'

Although the Eastern Europeans may have been convinced atheists, like Tatiana, raised in atheist families during the communist era, these clergy still believe that they will have 'something under the skin': people from Eastern Europe don't need to be tested like Western-background converts, since they are perceived as somehow intrinsically Orthodox. However, while it is easy to identify objective social and cultural differences in the conversion accounts of those from the East and the West, these differences do not seem to correspond to those cited by the priests.

When people explain why they have embraced a new faith, they will often construct their stories 'drawing on a socially available set of plausible explanations or rhetoric', and they may reinterpret ' past experiences in relationship to the new meaning system' (McGuire 1997, 74). Moreover, suggests McGuire, religious groups often encourage one preferred rhetoric for the construction of conversion accounts (ibid). In other words, such accounts must be analyzed as precisely accounts, and as such they may differ from what actually happened in the past. What I present in the following are thus the accounts people have chosen to convey to me, an outsider, several years after they became Orthodox, and these accounts are very likely influenced by the way they have since integrated Orthodoxy into their own lives.

I will present the accounts of six people: three with an Eastern European background and three with a Western background. These have been 
selected from among the 38 newcomers I have interviewed, and although it is with great caution, I will argue that these six accounts legitimately represent recognizable trends, in the sense that they illustrate the variation I have identified.

\section{Why Orthodox?}

\section{'I learnt to prove that God does not exist'}

Tatiana, who is Russian, was baptized as a child, but 'only as a kind of traditional thing'. From a very young age she was taught that God didn't exist, that religion was forbidden, and that 'there will be problems if you're seen visiting a church'. Later, she studied atheism, and while at university she wrote an essay on the scientific proofs against God's existence. Tatiana was apparently rewarded with much praise for this essay, and although she admits having expressed pride at the time, she now insists that she 'didn't feel good inside.'

In the 1990s she married a non-religious ethnic Norwegian man and moved to Norway. Tatiana was still a committed atheist, and she was 'only thinking about materialistic values'. She found a good job and she was content. 'It was a quiet period and finally I had time and energy to consider more than survival'. Then Tatiana found a book on how to cleanse the body and mind through meditation, and she suddenly

discovered that there is something above, and that is God. [...] In the beginning it was intellectually confusing, but I believe God then intervened in me. Imagine, I had to come all the way from Russia to Norway and I had to become 40 years old before I returned to the faith in which I was baptized.

When I studied philosophy at the university it was so confusing with the different truths. Even then I said to myself, this is impossible. There has to be only one truth! When I found that truth, I had to learn everything anew; how to live and how to seek salvation. You know, previously I had used my mouth to speak against God, but now I can use my mouth to speak up for God. I have been allowed to atone!

Tatiana is now divorced, but she is still content because 'God guided' her to her new church. She does not consider Norway a truly Christian country: like most of the world, says Tatiana, Norway is increasingly dominated by 
anti-Christian, i.e. satanic forces, as Russia was during the communist era. She believes there is an existential struggle going on, and she is fearful of accepting changes which may weaken the Orthodox Tradition and thus make the Orthodox more vulnerable. Consequently she resists all changes that she suspects constitute an innovation.

\section{'There was no way out....'}

Although her family was not religious, Miljana was baptized as a child. In Yugoslavia, at that time, the Church was 'almost forbidden', and Miljana herself rejected religion as 'nonsense.' For her, the atheism she was taught in school represented the truth, and she considered religion as meaningful only for uneducated people. Miljana received a higher education, found a good job, married and had children. Until the civil war started, she was apparently content, but then everything changed dramatically. Miljana and her family lived in Sarajevo, and she describes the years of war as terrible. It was precisely at this time, however, when 'there was no way out', that Miljana started thinking about God, and eventually she became a believer. When she and her family arrived in Norway as refugees, she immediately joined the Serbian congregation in Oslo. Miljana describes herself as a believer, but as she emphasizes 'a sensible believer, not an extremist'.

Although Miljana's husband and children haven't embraced her faith, they reacted positively to her desire to have them baptized in the famous Ostrog monastery in Montenegro.

Miljana loved the old multicultural Sarajevo, and she has yet again developed relationships with some of the Bosnian Muslims and Croatians who like herself fled to Norway. She has re-visited Sarajevo, but 'now it is their [the Muslims'] town; we [Serbs] don't belong any longer.' Miljana and her family were previously proud of their identity as Yugoslavs, but when Yugoslavia disappeared, they started identifying as Serbs.

They now visit Serbia every year, and Miljana has become a firm believer in the need for Serbs to stick together. She accepts all Orthodox Churches as equal parts of The Orthodox Church, but she strongly believes that all Serbs should join the Serbian Church. Unlike Tatiana, Miljana is not very concerned about what constitutes correct Orthodoxy; her concern is to make all Serbs in Norway join the Serbian congregation. 


\section{'Life is a continuous prayer'}

Nataliia was raised as an atheist in Bulgaria, and she was 30 years old when she was baptized. Her parents were not religious, but her grand parents were 'perhaps a little religious'. Fearing the communists, this had apparently never been mentioned in front of the children. In the turmoil after the fall of the communists, Nataliia describes how Orthodoxy became very popular, and she too, started for the first time reflecting on spiritual questions. Visiting Orthodox churches, she was fascinated by the liturgical singing, and she began experiencing 'inner calm', though she was still confused by the liturgical rules, and she felt uncomfortable having to kneel in order to pray. Then something happened to her, and she suddenly realized that she was 'kneeling in front of God.'

Nataliia continued, however, searching for inspiration within other religions too, and she says she can experience 'the same, deep warm feeling in Buddhist temples as in Bulgarian monasteries. It doesn't matter to which religious tradition a holy place belongs, but because we are humans we need specific material expressions. And to me as a Bulgarian, the expressions of the Bulgarian Orthodox Church are of course the most familiar'. Nataliia prefers the Bulgarian Church for linguistic, cultural and social reasons, and because she wants to support the Church which 'helped save the Bulgarian nation throughout centuries of oppression'.

Nataliia has now studied the liturgical texts, and in Norway she sings in the church choir. She claims to have 'a spiritual relationship to life', and to her 'life is a continuous prayer'.

\section{'A church which is truly the church of Christ'}

Harald grew up in a small town in the Norwegian Bible belt. His parents were believers, and he was baptized in the Norwegian Lutheran Church. Harald went to Sunday school, and later he joined one of the Free Churches. Due to political disagreements, however, Harald later left this church and began 'searching, but for what?' Leaving Christianity was apparently never an option, as he felt Christianity had 'a claim on' him. He was interested in theology and church history, but finding a new church was difficult. Increasingly frustrated, Harald began questioning whether there was any 'church which is truly the church of Christ?'

Converting to Catholicism was never an option, as he was unable to find support in early sources for the Catholic teachings on the infallibility of the Pope. Nonetheless, it was through an intellectually rewarding 
friendship with a Catholic priest that Harald was introduced to the Orthodox Church.

Vacationing in Greece, Harald started reading Bishop Kallistos Ware's books on Orthodoxy, and as he developed an interest in icons he contacted one of the Orthodox priests in Norway. As he felt warmly received, he asked about the procedures for becoming Orthodox. At the time there was no procedure for catechumens in place in Norway, and the priest simply told him to buy a prayer book, attend the Liturgy, and start fasting.

When asked why he finally decided to convert, Harald refers to Orthodox ecclesiology and dogmatics, the ritual cycle, and the Orthodox idea of 'a god who is truly God'. Although Harald speaks about this at length, he also emphasizes having had mystical experiences during the Liturgy as important. And as he integrated the ritual cycle in his everyday life, he discovered 'another kind of life behind the formal aspects of the rituals', and thus he began feeling closer to 'what life is about'. Gradually he developed an attachment to the Orthodox Church and has since remained faithful.

'In the Orthodox Church there are loads of traditions, but - there is always a but...' Gunnar was baptized in the Norwegian Lutheran Church, but his parents were not very religiously active. As a young man he converted to the Mormon Church and he spent time at a Mormon college in USA. Realizing that 'everything wasn't according to the idealized descriptions', he returned home and later he converted to Catholicism.

Gunnar describes the atmosphere in his Catholic congregation in the 1970 s as open and inspiring. However, when a number of highly vocal conservatives, opposed to the liberalization within the Norwegian Lutheran Church, converted to Catholicism, this changed. Being gay, he no longer felt at home.

Vacationing in Greece, Gunnar and his partner made friends with a family who introduced them to the daily life in an Orthodox congregation. Gunnar was fascinated by the relationship between laity and clergy, and by the Orthodox attitude to authority. 'In the Orthodox Church there are loads of traditions, but the Orthodox are quite laid back concerning how they practice them. There is always a but, and that makes the Orthodox more humane.' Thus Gunnar started reading books on Orthodoxy.

It was important to Gunnar how he and his male partner were received. Although some Orthodox Church leaders are very outspoken against homosexuality, the bishops in the Russian Orthodox archdiocese for Western 
Europe, to which their congregation belongs, have, according to Gunnar, 'never been anti-gay.' The local priest told them the Orthodox Tradition 'does not support a homosexual lifestyle', but they were still warmly welcomed. After 15 years as a Catholic, Gunnar converted again.

\section{'The liturgy is like a cosmic drama, it speaks to all senses'}

Trine's family wasn't religious, but she was baptized in the Norwegian Lutheran church and she describes herself as 'a religious child'. Around the age of ten, she started painting icons, and she developed an interest in Russia. Trine went to a 'good' Christian (Lutheran) high school, but she disliked the kind of Christianity dominating the school. She was in contact with the Catholic Church, but it was to Orthodoxy she was attracted, and she started attending the Liturgy when she was 14-16 years old. When she was nineteen she converted.

While Trine considered the preaching she had been exposed to previously 'banal', she experienced Orthodoxy as challenging - and satisfying. Orthodox Christianity was 'mystical', not something 'one could grasp intellectually'. 'It was not explained to pieces', and thus its spiritual message never became banal. Trine was fascinated by 'the holistic Orthodox theological understanding'. It is 'like a building in which every detail has its specific meaning; it resembles a Gothic cathedral.' And 'the Liturgy is like a cosmic drama speaking to all the senses.'

Trine says, 'The Church means a lot to me, but I am perhaps not a typical convert; I am too sloppy. I cannot stand having to perform, and thus I react negatively to all the instructions about what the Orthodox should and shouldn't do. To me it is more important to learn about sacralization.'

In social terms, Trine describes herself as an outsider, unconcerned about social status and materialist values. She wants to avoid a career which 'may damage my soul', and she feels Orthodoxy has inspired her to search through prayer for the best way to use her own capabilities. As she has periodically lived far away from Orthodox congregations, she has sometimes felt lonely. Still, while praying the ancient prayers by herself, Trine sometimes experiences 'a deep feeling of attachment to the Christian community'.

\section{Are they all converts?}

All the 38 people I have interviewed have made the same decision to (re-) join the Orthodox Church, and they are all, to varying degrees, commit- 
ted to Orthodoxy. Except for Trine, who converted at the age of 19, and another Bulgarian girl, who was baptized when she was 18, they have all joined the Orthodox Church in their late twenties or older. Among the thirteen Eastern Europeans there are five men and eight women. Among the 24 Westerners there are fifteen men and nine women. With very few exceptions they are all highly educated. Other studies of (Western) converts to Orthodoxy indicate that this represents a wider trend (see for example Hvithamar 2006, Slagle 2011). It is of course highly unlikely that this is the case in Eastern Europe, where the new believers represent a mass phenomenon. In Western countries, however, the Orthodox Church is still marginal, and thus, people have to make a particular intellectual effort to find it.

Although the Eastern Europeans and the Westerners in my sample share features like age, gender and level of education, there are some important differences between them.

\section{Western Christians/Eastern European atheists}

While all the Westerners have a Christian background, and the majority of them had been active Christians prior to their conversion, this is only the case for one of the thirteen Eastern Europeans. All the 24 Western converts were baptized as babies, and the majority were raised in religiously active families. ${ }^{2} \mathrm{~A}$ few were not, and like Trine, they somehow decided to follow a path different from their parents. Among those raised within a Christian environment, a few have apparently had shorter 'anti-religious' periods, before they again returned to Christianity and embarked on a spiritual search for better Christian answers.

The Westerners had previously been affiliated with a wide range of Christian groups: the Norwegian Lutheran Church, the Catholic Church, the Pentecostal movement, the Methodist Church, charismatic Christian groups, Youth with a Mission, and the Mormon Church. A few of them passed through several denominations in their search for a new spiritual home, but whether their different 'stops' actually involved conversions, varies. While Gunnar developed a 'conversion career', others may better be described as having merely 'visited' other denominations.

2 In Hvithamar's study of Danish converts, the majority were likewise baptized as babies, but they were apparently raised in religiously passive families (2006). The majority of the American converts to Orthodoxy studied by Slagle, however, were raised in families in which 'personal religious conversion and change were well-established features' (2011, 43-4). 
A few have visited non-Christian groups, too, for example Buddhist. Such people may still to some extent argue against the importance of religious boundaries, but generally they too strongly identify as Christians.

Among the Eastern Europeans, on the other hand, only one was raised as a Christian. He converted to the Orthodox Church simply because he perceived its teachings on homosexuality as less harsh than the Catholic. Being gay, he preferred the Orthodox idea of homosexuality as a 'disease' rather than the Catholic idea of a ' $\sin ^{\prime} .^{3}$ All the others were raised as atheists. Although three were baptized as infants, they strongly emphasize that this was only done as 'a traditional thing'. When growing up they had apparently nothing but contempt for those in need of religion.

In Christian theology, however, having been baptized one cannot become unbaptized; from a theological perspective, Tatiana and Miljana thus remained formally Orthodox, in the sense that they could return to the Church without any initiation rituals. The question is however, on what level it is meaningful to describe them as having been Orthodox all the time. Aren't they better described as converts, or perhaps reverts or reconverts? ${ }^{4}$

Taking a closer look at Tatiana's and Miljana's accounts, it is notable that they emphasize their transformation from atheism to Orthodoxy. What this transformation actually involved may vary, and it is obvious that Tatiana is more concerned about remaining on what she considers a correct Orthodox path than Miljana (or Nataliia). For Tatiana, it would be unthinkable to compare Buddhist temples with Orthodox churches, as Nataliia does. However, both Tatiana and Nataliia emphasized how much they needed to learn. Nataliia spoke of the confusing liturgical rules and her initial discomfort at having to kneel while praying. Tatiana explained that she had to learn 'everything anew'. Obviously these women did not feel that they had Orthodoxy 'under the skin'; neither did they have any Orthodox support systems in their backgrounds to rely on.

3 According to this informant, the Catholic Church in his home country described homosexuality as 'a sin which has to be punished', while the Orthodox Church considered it 'a sin caused by disease and as such it must be treated with understanding'. To him it was much preferable to be described as sick, and thus he converted. His priest has subsequently helped him come to terms with his homosexuality, and he is presently living with a partner. 4 Both terms refer to people returning to their original faith, and have mostly been used by Muslims: a revert is someone who discovers that he/she is (as all people are) meant to be a Muslim. The term reconvert has been used about nominal Muslims who become active believers (Roy 2012, 180). The same term is presently being used about Copts in Egypt who have converted to Islam and then later want to reconvert to the Coptic Church (UNCRIF 2013, 10). Both terms are sometimes used by scholars, see for example Slagle $(2011,11)$. 
Tatiana discovered Orthodoxy after she had moved to Norway and had married into a non-Orthodox family. Miljana's parental family was not religious, neither was - or is - her own family. The fact that her grandparents were somewhat religious was hidden from Nataliia when she was younger. In other words, these women grew up as content atheists, unfamiliar with Orthodox beliefs and practices, in countries where the Orthodox Church had been suppressed for decades and open religiosity represented a risk.

Like the Westerners, many of the Eastern Europeans started by searching through books and the internet, ${ }^{5}$ and a few in each group likewise passed through various religious groups until they found the Orthodox Church. ${ }^{6}$ The circumstances for their quests were however different. While the Westerners may have experienced personal crises, none of them mentioned this in relation to their spiritual quest and final conversion. All of the Eastern Europeans, however, related their conversions to their experiences of the political, social and economic crises in their home countries. It was during or after these crises that they started searching for a new system of meaning. It was only when there was 'no way out' that Miljana started thinking about God and the Church in which she had been baptized. Tatiana didn't start until she could relax from the pursuit of survival. Nataliia started after the fall of the Communist regime, when the Orthodox Church regained immense popularity in Bulgaria.

In their accounts, on the other hand, the Westerners, who were already Christians, emphasize their search for more satisfying Christian answers. Apart from Trine, who found her way to Orthodoxy alone, through a fascination with Russian culture, the others had mainly searched through texts. Rewarding personal encounters were emphasized, and vacations in Greece appear to have inspired some. Although they were religiously dissatisfied, none was desperate, and thus they spent much time pursuing their quest for what they describe as a Church in which God is truly God; the most authentic Church; a Church for both body and soul; a Church focusing on the individual as part of the collective; a mystical Church which doesn't at-

5 A Bulgarian woman describes how she started reading spiritual books in Norway. 'I was reading continuously; searching for answers. Then I came across a book by a Bulgarian Archimandrite and while reading I knew this was the right thing! I felt the presence of a mature, spiritual man, and it was as if he was speaking directly to me. Then I felt safe, and gradually I began feeling inner peace'. Then she asked to be baptized.

6 A Moldovian woman, baptized as a child, grew up as an atheist. Before returning to Orthodoxy she was interested in astrology and theosophy, and she 'visited' the Adventists, Jehovah's Witnesses, and various New Age inspired groups. The turning point came while she was listening to a cassette recording of the sermons of a Russian preacher. 
tempt to explain the unexplainable, etc. ${ }^{7} 23$ of the 24 Westerners were highly informed about Christianity, and they were very articulate when explaining their views on ecclesiology, rituals, etc., and why they prefer the mystical aspects left unexplained. Converts are often challenged and interrogated by family and friends, and therefore have to learn how to rationalize and justify their choices (Roy 2013, 184). In the case of these Orthodox converts, their Christian past and their educational level naturally increased their ability to do so.

Since the Eastern Europeans are rarely considered converts, they are not so much asked why they have chosen the Orthodox Church as when and how they became religious, i.e. rediscovered their 'inherent' Orthodoxy. Apart from the gay man who left the Catholic Church and joined the Orthodox for specific theological reasons, and who was very well able to put this into words, none of the other Eastern Europeans interviewed responded to my questions by putting forward their views on theology or ritual practices. Their concern was to communicate how and when they found Orthodoxy, or how they experienced that God actually intervened in them. When the Westerners were speaking of experiencing inner change, for example when Harald explained how he gradually discovered another reality behind the rituals, their transformations were described as part of a process; the Eastern Europeans, however, tended to emphasize an abrupt change, making the before and after vastly different. In this sense, the Eastern Europeans appear to fit even better into McGuire's concept of conversion as entailing 'a transformation of one's self concurrent with a transformation of one's basic meaning system' (McGuire 1997, 71). Although there may be variations concerning what their transformations actually involve - there is for example a big difference between Tatiana who fears going astray yet again, and thus attempt to do everything correctly, and Miljana who more than anything emphasizes that she is not an extremist, they all talk about having gone through an important change.

Though the Westerners generally accept being called converts, they may sometimes question whether they should actually be categorized as such, since they have been Christians all their lives. In other words, they perceive their choice to become Orthodox as involving a development of their Christian faith, rather than a break with their past or a radical transformation. One referred to Orthodoxy as having existed within him as a latent belief, arguing that he had never converted, but 'had only pursued

7 These reasons are also mentioned by the American converts to Orthodoxy studied by Amy Slagle (2011, 84ff). 
the faith I received as a child'. They tend however to be quite outspoken on the deficiencies of the beliefs and rituals in their previous denominations, and they tend - naturally - to argue quite strongly in favor of Orthodoxy. ${ }^{8}$ Thus, when explaining why they became Orthodox they indirectly confirm that important aspects of their beliefs and practices have in fact been transformed. They have also passed through a more or less formal catechumenate and they have been formally initiated into the Orthodox Church, and consequently, it seems unproblematic to categorize them as converts, as the Orthodox themselves tend to do. ${ }^{9}$ But what about the Eastern Europeans: how should they best be categorized?

To describe the gay Catholic who became Orthodox, as a convert, and not Miljana and Nataliia, because they were baptized as babies, seems odd. From their accounts, it is obvious that their transformations involved a lot more than his did. They may of course be categorized as reverts or reconverts, but the point is that these women, and the ten others who grew up unbaptized, have - to various degrees - transformed their worldview and their perception of themselves, and thus, they too fit the analytical definition of a convert.

As mentioned above, the Orthodox Church wants a particular kind of converts, i.e. 'religious pilgrims', who will adhere wholeheartedly to its beliefs, rituals and practices. But is this what it gets?

\section{Religious pilgrims: the exception within the exceptional case?}

Converts are often described by their co-religionists as zealous, i.e. as too obedient and too concerned about correctness. This is also the case among the Orthodox in Norway, who may criticize (other) converts for 'dressing and acting as if they are monks or nuns', and diagnose them as 'suffering from convert-disease'. When Trine described herself as 'perhaps an untypical convert', she seemed to take it for granted that other Orthodox converts are willing 'to perform', which she is not, and that they are not 'sloppy' as she is. In other words, by emphasizing how she is different from the others, Trine too, confirms the prevalent assumption of what converts are

8 In contrast to some American and British converts, none of the converts in Norway referred to liberal attitudes concerning female priests and/or homosexuality as reasons for their own conversions. Interestingly the only two who referred to such debates were the two gay men who had left the Catholic Church because of its negative attitude to homosexuality.

9 They may also be placed in the subcategory which Hervie-Léger calls 'converts from within', i.e. converts who redefine what they perceive as an existing latent belief (Kaoues 2013, 25). 
like. Based on my data, I will however question this assumption, and I will argue that although Trine's way of describing herself seems untypical, her independent way of practicing Orthodoxy is more or less typical among the converts in Norway.

The 38 converts I interviewed constitute a very diverse group, but what they seemed to share was a strong attachment to the Orthodox Church and a strong will to make independent decisions on how to be Orthodox. As they had all made their own decisions to join the Orthodox Church on the basis of their own evaluations, they valued their independence, and they were clearly not going to passively wait to be told what to do. Although they were attracted to the Orthodox Church because of its authenticity, its unwillingness to 'discuss everything to pieces', they apparently felt free to evaluate what is correct Orthodoxy and to decide what is obligatory and what isn't. As Trine put it, 'it is the goal, sacralization, which is important, not all the instructions about what an Orthodox has to do!'

Orthodoxy constitutes a complex system, with a strong emphasis on oikonomia, i.e. the need for understanding and compassion, and this provides space for individual considerations. This combination of conservatism and oikonomia is obviously attractive to some, for example Gunnar, who described the Orthodox as 'more humane', because 'there is always a but...'. And clearly, not only Trine, but most Orthodox converts appear to relate to such 'buts'; they are not willing to perform for the sake of performing. In principle, exemption from duties should be discussed with their priests; it is the priests who have the authority to exercise oikonomia in their guidance for the laity. Orthodox converts, however, often make such decisions themselves. This does not imply that they aren't wholeheartedly Orthodox; on the contrary, they appear precisely to be searching for the most suitable way - for them - to be Orthodox.

Tatiana, who is scared of 'going astray once again', would of course never describe herself as 'sloppy', but since she is very concerned about doing everything the correct way, she is constantly struggling to decide what this actually involves. She has great respect for her local priest, but she is by no means willing to listen to him if she isn't totally convinced that his interpretation is correct. When her congregation discussed changing the calendar in order to adjust its Christmas celebration to the 'Norwegian' celebration, the priest was prepared to accept this, but Tatiana was not, and she searched for other authorities to support her resistance towards this change. Fearing that members like Tatiana would leave the congregation ended the debate. 
The Orthodox are supposed to attend the Liturgy every Sunday if possible, and they are supposed to confess before receiving communion. Not everybody agrees with such rules. Disliking having to confess 'when there is nothing to confess', one very dedicated convert decided to transfer from his original congregation to another, which agreed to allow him to decide for himself when confession was necessary. Although her priest is less than content, another convert sometimes decides 'to enjoy God's own nature' rather than attending the Liturgy on Sundays, since she feels that 'encountering God in the woods may sometimes be of equal value.'

Although the Orthodox are supposed to fast during the prescribed periods, if not exempted by their priest, quite a few converts appear to decide for themselves whether to fast or not. While they may consider the fasts as important in defining the Orthodox, and connecting them to the ancient Christians, not all of them always participate. When I asked Miljana whether she fasted, she simply said no. Although firmly attached to her new identity, fasting apparently wasn't part of what she considered obligatory. Another convert with little enthusiasm for fasting defended his view by referring to the Bible, saying: 'what goes out of the mouth is more important than what goes in!' In other words, refraining from speaking ill of other people is more important than abstaining from certain kinds of food at specific times. Others referred for example to health problems, personal problems, and/or problems at work. While their priests most probably would have agreed to exempt them from the fasting requirements for at least some of these reasons, they obviously didn't feel the need for clerical approval.

The Orthodox are supposed to perform daily prayers and veneration of the saints, read the Bible, and attend the Liturgy every week. However, while some converts, like Tatiana, attempt to fulfill these requirements, others, like Miljana, don't.

For Miljana, being Orthodox is all about her belief in God and her attachment to the Orthodox Church. She goes to church most Sundays, perhaps as much for social as for spiritual reasons; she celebrates the major feasts and she visits famous monasteries because it makes her proud and it makes her feel good. Naturally she prays and read the Bible sometimes, but she hasn't established a regular routine as she is supposed to. Miljana participates however in the running of her congregation, and she puts considerable effort into encouraging all Serbs to come together and celebrate their membership in the Serbian Orthodox Church. 


\section{Believing, belonging - with independence}

Although describing herself as 'sloppy', Trine emphasized that 'the church means a lot to me!' And clearly, the Orthodox Church is important in these converts' lives. In spite of their independence, they all participate actively in their congregations. The unwillingness to perform expressed by some converts should perhaps be understood as conveying a deeper desire to be truly Orthodox. By rejecting what they consider empty words and empty performances, they emphasize that they want to be sincere: to go beyond the formalities towards the true reality.

All these converts have been Orthodox for some years, and have already proven themselves as catechumens; they have been certified, and they have passed the first phase (during which even Trine admits to having been concerned about formalities). In a sense they are passed beyond becoming Orthodox; they are Orthodox and they do belong. Thus, they may feel able to move on to a deeper level behind the formalities, and/or they may simply feel free to relax a bit.

While there may be differences in regard to how Eastern Europeans and Westerners speak about their way of practicing Orthodoxy and/or how they relate to clerical authority, the similarities regarding what they actually do are striking. They all care deeply for their Church, but they are also openly critical, and they do all make independent choices concerning their practise. They cannot, in other words, be categorized as religious tourists, people in constant movement towards greater fulfillment, whom Bauman and Ahlin claim are typical of the conversion phenomenon today (Ahlin 2005, 17).

One prominent convert has left to become Catholic. Apparently he didn't question Orthodoxy as such, but became tired of the intra-Orthodox conflicts in the diaspora, and decided to move on. Another has stopped coming to church for reasons unknown. The other converts are still practicing Orthodox, and I will argue that they may be categorized, more or less, as religious pilgrims, who adhere wholeheartedly to a coherent belief system (ibid). Although 'wholeheartedly' is a strong term, and it is obvious that these converts relate to Orthodoxy in a variety of ways, it is equally clear that Orthodoxy constitutes for them an important system of meaning. While they may sometimes criticize the Orthodox Church and its leaders, they still maintain their attachment to this Church. Perhaps precisely because they consider it their church, they may consider it important, and their right and duty, to express independent views and critique. Doing so may thus actually be seen as a confirmation of their belonging. 
According to Grace Davie's line of thought, these converts' desire to both believe and belong makes them different from the majority of converts in Western Europe. Davie argues, as cited above, that Western Europe presently is dominated by people 'believing without belonging' and/or 'belonging without believing' (2002). In this context the converts to Orthodoxy, both those with a Western and an Eastern European background, constitute an interesting exception.

BERIT THORBJØRNSRUD is Associate Professor at the Departement of Cultural Studies and Oriental Languages, University of Oslo, Norway. E-mail: b.s.thorbjornsrud@ikos.io.no.

\section{Bibliography}

Interviews

'Tatiana' Oslo 12 May 2006

'Miljana' Oslo 22 October 2006

'Nataliia' Oslo 26 June 2006

'Harald' Oslo March 2006

'Gunnar' Oslo 28 February 2006

'Caroline' Oslo 24 April 2006

\section{Literature}

\section{Ahlin, Lars}

2005 Pilgrim, turist eller flyktning? En studie av individuell religiös rörlighet $i$ senmoderniteten. Eslöv: Symposion.

\section{Chaillot, Christine (ed.)}

2006 A Short History of the Orthodox Church in Western Europe in the 20th Century. Paris: Inter-Orthodox Dialogue.

\section{Davie, Grace}

2002 Europe: The Exceptional Case. Parameters of Faith in the Modern World. London: Darton Longman Todd.

\section{Hervieu-Léger, Danièle}

1999 Le Pèlerin et le converti. La religion en mouvement. Paris: Flammarion. 


\section{Hvithamar, Annika}

2006 Det ortodokse Dagmarkors - om conversion til den ortodokse kirke i Danmark. Magasinet Humaniora (1), 12-15. Offprint.

Kapalò, James A.

2014 Mediating Orthodoxy: Convert Agency and Discursive Autochtonism in Ireland - Maria Hämmerli \& Jean-Francois Mayer (eds), Orthodox Identities in Contemporary Western Europe: Migration, Settlement and Innovation, 229-50. Farnham, Surrey: Ashgate.

\section{Kaoues, Fatiha}

2013 Evangelicals in the Arab World - Nadia Marzouki \& Olivier Roy (eds), Religious Conversions in the Mediterranean World, 13-27. Basingstoke: Palgrave Macmillan.

\section{Marzouki, Nadia \& Olivier Roy (eds)}

2013 Religious Conversions in the Mediterranean World. Basingstoke: Palgrave Macmillan.

\section{Marzouki, Nadia}

2013 Introduction - Nadia Marzouki \& Olivier Roy (eds.), Religious Conversions in the Mediterranean World, 1-12. Basingstoke: Palgrave Macmillan.

\section{Mathewes-Green, Frederica}

2006 Facing East. A Pilgrim's Journey into the Mysteries of Orthodoxy. San Francisco, CA: HarperSanFrancisco.

\section{McGuire, Meredith B.}

1997 Religion. The Social Context. Belmont, CA: Wadsworth Publishing Company

\section{Roy, Olivier}

2013 Conclusion: What Matters with Conversions? - Nadia Marzouki \& Olivier Roy (eds.), Religious Conversions in the Mediterranean World, 175-87. Basingstoke: Palgrave Macmillan.

\section{Slagle, Amy}

2011 The Eastern Church in the Spiritual Marketplace. American conversions to Orthodox Christianity. DeKalb, IL: Northern Illinois University Press.

\section{Thorbjørnsrud, Berit}

Forthcoming 'The Problem of the Orthodox Diaspora'. The Orthodox Church between Nationalism, Transnationalism and Universality. Numen. International Review for the History of Religions.

\section{UNCRIF Report}

2013 United States Commision on International Religious Freedom, Annual Report. 
Websites

\section{Andrews, Fr. Richard Demetrius}

n.d. Catechism \& Conversion. - Saint George Greek Orthodox Church, Greek Orthodox Metropolis of Chicago. <http://stgeorgegoc.org/pastors-corner/ catechism-conversion>, accessed 12 July 2013.

Anon.

2001 On becoming and remaining an Orthodox Christian. A Talk given at the Orthodox Pilgrimage to Felixstowe in August 2001. - Orthodox England on the 'net. St John's Orthodox Church, Colchester, UK. < http://orthodoxengland.org.uk/brorthoc.htm>, accessed 21 August 2013.

\section{Garvey, Fr. John}

1996 A typology of converts: beware of those running away - Diocese of New England, Orthodox Church in America. < http://www.dneoca.org/ articles/typology0197.html>, accessed 31 May 2015. 
